\title{
Improving the analysis of road pricing acceptability surveys by using hybrid models
}

\author{
Floridea Di Ciommo ${ }^{\mathrm{a}, *}$, Andrés Monzón ${ }^{\mathrm{b}}$, Alvaro Fernandez-Heredia ${ }^{\mathrm{c}}$
}

\begin{abstract}
A B S T R A C T
Several international studies have analyzed the acceptability of road pricing schemes by means of an attitude survey in combination with the results of a stated choice experiment using both a descriptive analysis and a discrete-choice model with binary choice ("accept" or "not accept" the toll). However, the use of hybrid discrete choice models constitutes an innovative alternative for integrating subjective attitudes and perceptions deriving from the survey of attitudes with the more objective variables from the stated choice experiment. This paper analyzes the results of applying these models to measure the acceptability of interurban road pricing among different groups of stakeholders (road freight and passenger operators, highway concessionaires, and associations of private car users) with qualitatively significant opinions on road pricing measures. Our results show that hybrid models are better suited to explaining the acceptability of a road pricing scheme by different groups of stakeholders than a separate analysis of the survey of attitudes and a discrete-choice model applied on a stated choice experiment. A particular finding was that the strong psycho-social latent variable of the perception of fairness explains the rejection or acceptance of a toll scheme by road stakeholders.
\end{abstract}

\section{Introduction}

Experience has shown that the introduction of road pricing is a controversial topic (Jones, 1998; Schade, 2003; Ison and Rye, 2005; Gaunt et al., 2007). The European Commission has started on a path towards the gradual introduction of charges to encourage efficiency and at the same time to compensate for the ecological damage caused by road transport (CEC, 2001, 2008). A number of European Directives foster the deployment of a European common toll system: Directive 2006/38 on the charging of Heavy Good Vehicles (HGVs) for the use of certain infrastructures (CEC, 2006, 2008, 2011); Directive 2008/0147 includes the regulation of future road pricing based on external costs; and the Directive 2011/76.

Various European studies have addressed the issue of the acceptability of road pricing schemes for passenger and freight transport (Jakobsson et al., 2000; Link and Polak, 2003; Jaensirisak et al., 2005; Link, 2007; Vrtic et al., 2007; Winslott-Hiselius et al., 2009), and systematic studies of prevailing trends in public opinion based on polls taken before and after the implementation of road pricing measures have been carried out in several European countries (Kottenhoff and Brundell-Freij, 2009) and American states (Ungemah and Collier, 2007).

Spain has a network of $13,156 \mathrm{~km}$ of interurban highways (MIFO, 2007), of which only $2814 \mathrm{~km}$ are tolled sections. Like all EU countries, Spain is obliged to consider the European Union's transport policy and the regulations enacted to define and 
promote a fair and homogeneous generalized road pricing system. A survey of public opinion revealed differing attitudes toward country-specific pricing measures in nine Nordic European countries (PATS, 2001), but no survey has so far addressed the acceptance rate for pre-implementation road pricing schemes in a southern European country such as Spain. Between November 2008 and March 2009 an internet-based survey on public acceptability was conducted as part of the META research project, whose aim is to define a Spanish road pricing model (Di Ciommo et al., 2010). The target population consisted of various groups of road stakeholders: Spanish freight and passenger road operators, highway concessionaires, associations of private car users, and some agents of transport policy. The objective was to capture different dimensions of acceptability vis-à-vis the potential implementation of a generalized road pricing system in Spain.

The current methods to assess road pricing acceptability are basically based on the analysis of attitudinal and perception questionnaires and stated preferences experiments (Link, 2007; Vrtic et al., 2007). Different studies analyze it through descriptive statistical analysis, or structural equations and even through discrete choice models (Pridmore and Miola, 2011). In this paper we propose a combination of those analytical tools to better understand the results. To this end a hybrid model has been developed. It allows integrating subjective attitudes and perceptions derived from an attitude questionnaire with a stated preferences experiment.

Despite the general agreement that environmental problems due to road passenger and freight transport are serious threats to the public welfare, proposed solutions such as the implementation of a road pricing system are not readily accepted. In other words, social responsibility is not a major variable in explaining the acceptability of road pricing (Pridmore and Miola, 2011). However, various other studies using a psychological approach show that a strong latent variable which explains the acceptability of tolls before the implementation of a road pricing scheme is the perceived fairness (De Groot and Steg, 2006; Eriksson et al., 2008). The proposed method completes the economic approach of the discrete choice model with attitudinal factors (Ubbels and Verhoef, 2006). Therefore the acceptability approach based on cost and benefits of toll is improved with an evaluation of individual attitudes towards pricing (Bamberg and Rölle, 2003; Jones, 2003; and Schade and Schlag, 2003).

The paper is divided into six sections. The second section - after the introduction - provides an overview of the state of research and methods to assess acceptability. It investigates the determinants of stakeholders' behavior, and shows how the integration of subjective attitudes into a choice model helps to identify barriers to public acceptance; it also identifies the potential supporters and opponents of pricing. The third section describes the research methodology used for the survey. Section 4 presents a descriptive and statistical analysis of the results. The fifth section contains the theoretical formulation of the hybrid discrete choice models, including latent variables. It also includes the main results comparing different statistical and modelling analyses. Section 6 draws conclusions as to the implications for road pricing policy as a result of the analysis of hybrid discrete choice models.

\section{Background}

\subsection{State of research methods on the acceptability of road pricing}

The degree of acceptability of toll-road pricing effects is a complex matter that can be analyzed in a number of ways, such as for example from a psychological and sociological standpoint (Schade and Baum, 2007; Kottenhoff and Brundell-Freij, 2009).

Three kinds of research and methods can be undertaken to analyze transport policy measures, and particularly road pricing policies. First, predictions about acceptability derived from theoretical models that rest on assumptions about individual behavior tested against the results of a road-user survey (Jakobsson et al., 2000; Schuitema et al., 2007; Eriksson et al., 2008). Second, individual attitudes can be analyzed by means of an empirical survey (questionnaire, interview, etc.) (De Groot and Steg, 2006; Link, 2007). Third, ex-post study permits the investigation of individual behavioral changes in response to specific policy measures (Swicher and Ungemah, 2006; Schade and Baum, 2007 and Winslott-Hiselius et al., 2009). The first approach is based on assumptions about individual behavior in a theoretical model that must be tested a posteriori, while the second derives from direct observations used to construct the hypothesis of an empirical model. Both approaches are based on two types of surveys. The first one is oriented to measure attitudes and perceptions using point scale questions. The second type uses stated or revealed preferences questionnaires to assess the acceptability before or after the transport measure implementation. Once we have collected data, there are three different methods to analyze the survey results; first a psychological analysis based on consistency tests (De Groot and Steg, 2006). Then, two methods based on modelling: discrete choice and hybrid choice models. The latter including attitudes and perceptions seems to be a more powerful tool for integrating the economical variables with a deep attitudinal construct, that is latent variable (Ben-Akiva et al., 2012). This paper approaches the question of the acceptability of road pricing by examining the collected primary data and integrating socioeconomic and psychological considerations using hybrid model.

\subsection{Acceptability links with perception of freedom, faimess and efficiency}

Several European studies confirm that the acceptance of road pricing by users is closely linked to the perception of freedom, fairness and efficiency (Verhoef et al., 1997; Jakobsson et al., 2000; Schade and Schlag, 2006; Ubbels and Verhoef, 
2006). In particular, the debate focuses mainly on the following subjects relating to the users' perception of fairness (1-3) and of the efficiency of the toll system (4-6):

1. Method used to calculate the road price.

2. Vehicles affected by the road charge.

3. Compensation measures to account for the fact that the road charge is imposed on top of existing taxes (on fuel, registration and licensing costs, etc.).

4. Time savings achieved and congestion problems avoided.

5. Use of toll revenues and trust in government and other agencies involved, such as toll revenue managers.

6. Toll collection system.

The acceptability of toll-road pricing become a complex matter that can be approached in a number of ways (Litman, 1996; Fridstrøm et al., 2000; Eriksson et al., 2008). Generally speaking, it is difficult to reach a compromise in a road pricing scheme when there are desired and competing objectives such as efficiency and fairness (Mayeres and Proost, 2002). The perception among certain social groups or transport sectors that road pricing measures are unfair has been one of the major obstacles to the implementation of toll schemes (Teubel, 2000). Most of the effects linked to the fairness of a road pricing policy relate to the ultimate use of the revenues collected by the toll and to the prevailing level of trust in government and in the other agencies involved (Jaensirisak et al., 2005; Frey, 2003). For the same reason, the management and use of the revenues is a key factor in guaranteeing acceptance of any road pricing policy that may be adopted (Rienstra et al., 1999; Schuitema et al., 2007). However there are relatively few studies focusing on the subjective perception of fairness (Eriksson et al., 2008). The results of this paper highlight the importance of this subjective perception for accepting a road pricing scheme.

\section{Research methodology and survey development}

The Spanish toll motorway network has been developed through concession schemes. Following the EU directive this system should be changed. The META research project settled the basis for a vehicle tolling scheme aimed at recovering maintenance, operation and external costs for the whole motorway network. The META proposal is based on average and marginal costs calculated for each vehicle type (car, HGV, LGV and bus) according to the interurban road characteristics (AADT, capacity and traffic composition for each section) (Di Ciommo et al., 2010).

Following this empirical model for costs, the proposal for a toll scheme would include a price range for roads of $€ 0.11$ per car-km to $€ 0.16$ per HGV-km. This result is fairly consistent with the current prices for tolled Spanish roads ( $21 \%$ of the total highway network), namely 60.086 per car- $\mathrm{km}$ and 0.16 per HGV-km (Di Ciommo et al., 2010). The introduction of a generalized road pricing scheme would represent the extension of the current toll to the entire Spanish road network, making the implementation of road pricing measures a highly controversial topic. Spanish freight operators have voiced their opposition to the introduction of a generalized road pricing scheme unless there is a revision of the national fuel charge equivalent to $54 \%$ of the fuel price (Vassallo et al., 2008). As a consequence, we decided to complement the research on the pricing with an analysis of stakeholders' acceptability. This is the first survey on road pricing acceptability carried out in Spain.

Data were collected through a self-administered internet-based survey among Spanish freight and passenger road transport operators, highway concessionaires and car users' associations. The aim was to capture different degrees of acceptability of the introduction of a generalized road pricing system in Spain. They were selected for META project because they are the most representative road stakeholder groups. The survey was conducted between October 2008 and March 2009. The sample was randomly selected by the operator associations from their databases, including companies of all sizes. The freight transport operator associations sent the survey to 250 associated enterprises, yielding 48 answers. The organization of passenger transport operators sent the survey to 30 transport operators, which resulted in 15 answers. With regard to highways, the concessionaire organizations sent the survey to 25 road maintenance and construction technical directors, and received 23 answers. The association of private car users sent the survey to its 20 regional offices, collecting 17 answers from their technical directors. The survey yielded responses from 114 road stakeholder groups, road transport companies and their collective organizations.

Although the sample size of 114 stakeholders could be considered rather small for reaching any conclusive determinations about public acceptance in Spain, this sample is qualitatively significant as all the road stakeholders who are most closely implicated in road use are well represented. In addition, with regard to the SP experiment, a sample of 114 observations produces a representative sample, as shown by Ben-Akiva et al. (2009). The survey results on the attitude statements are fairly similar for different kind of stakeholders. This result implies that the heterogeneity of the sample is not reflected in the heterogeneity of general attitudes as regards road tolls. A unique binary discrete choice model was therefore developed for all the stakeholders in order to explain their behavior. A breakdown of specific stakeholder groups is given only when their statement attitudes are significantly different.

The questionnaire consisted of three modules: the first contained questions regarding stakeholders' characteristics; the second consisted of an attitudinal questions; and the third offered various options which could be ranked in terms of stated preferences. Respondents were guaranteed that their responses would be anonymous. They were warned that time required to fill out the questionnaire was 7-10 min. No incentives were offered for responding. 
Table 1

Socio-economic characteristics of the respondents.

\begin{tabular}{|c|c|c|c|}
\hline Characteristics & Level & Frequency & Percentage \\
\hline \multirow{5}{*}{ Stakeholder groups } & Freight operators & 48 & 42 \\
\hline & Passenger operators & 15 & 13 \\
\hline & Highway concessionaires & 23 & 20 \\
\hline & Car user associations & 17 & 14 \\
\hline & $\begin{array}{l}\text { Experts (institutional and } \\
\text { administrative) }\end{array}$ & 9 & 11 \\
\hline \multirow[t]{4}{*}{ Annual turnover } & Less than $€ 1$ million & 6 & 5 \\
\hline & $€ 1-5$ million & 20 & 18 \\
\hline & More than $€ 5$ million & 80 & 70 \\
\hline & Not applicable & 8 & 7 \\
\hline \multirow[t]{2}{*}{ Freight operators of combined road and rail transport } & Yes & 26 & 54 \\
\hline & No & 22 & 46 \\
\hline \multirow[t]{3}{*}{ Logistical services offered by freight and passenger operators } & Yes & 36 freight +3 & 62 \\
\hline & & passengers & \\
\hline & No & 24 & 38 \\
\hline \multirow{5}{*}{$\begin{array}{l}\text { Number of vehicles per transport company (freight and passenger } \\
\text { operators) }\end{array}$} & Less than six vehicles & 5 & 8 \\
\hline & $6-20$ vehicles & 8 & 13 \\
\hline & $21-40$ vehicles & 7 & 11 \\
\hline & More than 40 vehicles & 38 & 60 \\
\hline & No answer & 5 & 8 \\
\hline
\end{tabular}

\section{1st part - Questions on stakeholder characteristics}

Table 1 details the socio-demographic characteristics of the respondents. A breakdown reveals that $42 \%$ of the sample population consists of freight transport operators, which is the most heavily represented road stakeholder group; $13 \%$ are passenger transport operators; $20 \%$ are technical agents from highway concessionaires; $14 \%$ are mostly members of private car and road associations; and $11 \%$ are experts from the institutional and administrative field. Specifically, $70 \%$ of the sample had an annual turnover of over $€ 5$ million, $18 \%$ between $€ 1$ million and $€ 5$ million, and only $5 \%$ less than $€ 1$ million. The rest $7 \%$ were experts from the institutional and administrative fields. Among freight operators, 54\% offered combined road and rail transport, while $62 \%$ offered logistical services. Regarding fleet size, $60 \%$ were big companies with more than 40 vehicles.

2nd part - Attitudinal questions

The main purpose of this part was clearly stated from the outset: to identify the key determinants which make a particular level of road pricing acceptable (Link, 2007). These determinants could be the latent variable indicators, including:

- Expectations and fairness perceptions of users regarding the extension of a road pricing system to the entire Spanish interurban highway network.

- Social responsibility for the environment and road safety.

- Evaluation of the efficiencies resulting from the introduction of road pricing measures.

The starting point for developing the attitudinal part of survey were the acceptance factors identified by Schlag and Teubel (1997) in their model of road pricing acceptability:

- Perception of transport problems (infrastructure damage, congestion, external and accidental costs).

- Design of charges (levels of charges and their variation depending on traffic congestion, type of vehicles, road type, and road quality).

- Effect on public approval of the institutional framework.

- Use of revenues in combination with different options for the institutional framework (who collects the toll charge and who is entitled to decide its use).

- Perceived utility of road-user charges in solving transport-related problems.

- Relationship between the social responsibility of users as to climate change, enhanced safety, and greater acceptability.

Therefore, we built the survey of attitudes focused on the following sets of attitudinal questions:

- Perception of road transport problems (six questions).

- Institutional framework and the use of revenue (three questions).

- Resulting beliefs and adaptation strategies of freight operators to the toll scenario (three questions). 
- Design of charges and perceived usefulness of road-user charges in solving transport-related problems (six questions).

- Effect on acceptability of the charging technology (two open-ended questions).

- The best design of toll charges, containing questions regarding the types of vehicles that should be charged and the road network to be taxed (urban and interurban). This is related to fairness, and whether to apply road pricing measures to all vehicle types and all road networks.

- Level of toll charge in application of EC Directives. Tolls for cars are ranging between $€ 0.06$ and $€ 0.09 / \mathrm{km}$, and for HGV between $€ 0.11 / \mathrm{vkm}$ and $€ 0.13 / \mathrm{vkm}$.

Responses to each question were collected using a four-point agreement scale ("strongly disagree”, "disagree” "agree” and "strongly agree").

3rd part - State preferences experiment

In order to define the relationship between different price levels and revenue spending options, the third part of the survey was a simplified stated-preference exercise. Respondents were asked to choose among different packages involving combinations of pricing and spending measures. Specifically, three different toll levels were presented to the respondents: an average toll of $€ 0.05 / \mathrm{km}, € 0.10 / \mathrm{km}$ and $€ 0 / \mathrm{km}$. The toll level of $€ 0.05 / \mathrm{km}$ corresponds to the minimum price value estimated by the META empirical model of costs, the amount necessary to cover the external costs for a car without road maintenance costs (Condeço-Melhorado et al., 2011). The toll of $€ 0.10 / \mathrm{km}$ is the price value calculated as summarizing external and maintenance costs for HGV for a highway section. In any case, the toll charge includes the cost of road construction. All toll levels were linked to the following three revenue-spending options:

- New road construction.

- Improvement of road safety.

- Climate change policy measures.

\section{Survey results}

\subsection{Attitude survey results}

The analysis of the attitudinal survey results could be summarizing as follows:

\section{(a) Perception of transport problems}

The Spanish road network is in good condition (59\% of respondents agree or strongly agree and only $6 \%$ disagree). But $50 \%$ of the stakeholders believe that in the future the government will not have sufficient revenues to maintain the roads in such good condition. Various differences in the attitude statements emerge when the analysis is performed on a stakeholder by stakeholder basis. The majority of transport freight and passenger operators consider that congestion problems will increase their operation costs and decrease the quality of the services they can offer clients, while the highway concessionaires (more than $50 \%$ ) do not totally agree with the statement that congestion problems will decrease the services that transport operators are able to offer their clients. Almost all respondents - $95 \%$ - consider that road safety problems should be a government priority. When it comes to the need for measures to alleviate climate change the percentage is lower: $46 \% .67 \%$ of freight operators do not agree at all, or neither agree nor disagree with the statement that the government should give priority to limiting environmental damage in its handling of the transport problem. Around $50 \%$ of the members of two stakeholder groups - passenger bus operators and highway concessionaires - answer that they neither agree nor disagree, while a majority of the car user association groups agree.

(b) Management of the road tolling system

The greatest level of support (77\% agree or strongly agree) was expressed for the proposal that the roads and highways agency should both collect the revenues and invest them in the maintenance of existing roads or in the construction of new ones. This percentage of agreement decreases to $26 \%$ if the institutional framework chosen to collect and use the revenues is an independent agency, and to $12 \%$ if the road pricing revenues contribute to funding the general budget, and if their use is decided by the government. The stakeholders disagree with the establishment of a toll agency to decide on the use of the revenues collected, even if it is independent of the government ( $51 \%$ disagree). The government is clearly not trusted to act properly as a manager (that is, as a collector and dispenser) of road revenues. In particular, there is a fear that the revenues collected will flow into the general government coffers and be spent on some other public services. Finally it is considered unfair to charge for road use and then to use the revenue collected on other services. Some stakeholder groups such as passenger bus operators, private car associations and highway concessionaires show less opposition to the establishment of an independent agency (50\% neither agree nor disagree), and the other $50 \%$ agree with the need for a road and highways agency to collect the revenues and invest them in the maintenance of existing roads or in the construction of new ones. 


\section{(c) Resulting beliefs and adaptation strategies of freight transport operators}

The majority of stakeholders, especially freight operators, consider that the implementation of a road pricing system will have some minor effects on the effectiveness of road transport (fewer empty trips, for example). A minority - $42 \%$-, particularly passenger bus operators and private car users' associations, think that a road pricing system is useful for developing better freight and passenger rail systems. Furthermore, the great majority (73\%) are skeptical that the introduction of a road pricing system would create advantages for air transport (through the modal transfer of both freight and passengers). The highway concessionaires and private car users' associations are confident that the implementation of a road pricing system will have an important effect on air transport (more than $50 \%$ agree or strongly agree that road pricing can have some effect on the development of air transport).

(d) Charging technology and acceptability (two open questions)

The open-ended responses as to the means whereby revenues are collected converge on two main solutions. First, $60 \%$ indicate that the best technological solutions are GPS or TAG and similar tolling systems, due to their compatibility with continuous free flow and the reduced need for vehicles to line up for payment. Second, $40 \%$ of respondents took the opportunity to emphasize their belief that road transport is already too heavily taxed and that a generalized road pricing system would not be justified without a simultaneous reduction in the overall tax burden. Present road users - and particularly freight operators - clearly do not want to pay to use highways that are currently free.

(e) Tolling scheme design

Spanish freight operators (75\%) appear to support a real-time congestion price with a charge related to road quality, more than the other stakeholder groups (62\%). This contradict the results of the survey among German freight operators, who rejected the suggestion of an additional toll to pay for congestion (Jaensirisak et al., 2005), Highway concessionaires are less in favor of a toll related to road quality (50\% disagree). In general, all stakeholder groups rejected the suggestion of a pricing system for urban roads (55\% disagree). $66 \%$ of the respondents agreed that all road users should have to pay the toll and $64 \%$, knowing that freight operators represent $43 \%$ of the sample, disagreed with a road charge applied only to HGV. A majority (59\%) agreed that road prices should be harmonized throughout the EU.

\subsection{Stated preference experiment results}

Each respondent was asked to choose among three different alternatives characterized by toll variations with an increasing investment in infrastructures, road safety and climate change policy measures. Three types of analysis were performed with the data collected from the stated preferences. The first, a simple descriptive analysis of stated preferences about each combination of toll levels and the possible uses of revenues obtained, is shown in Fig. 1. This simplified data analysis is effec-

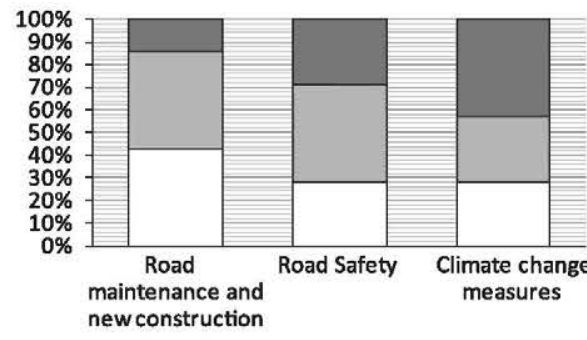

Car users associations

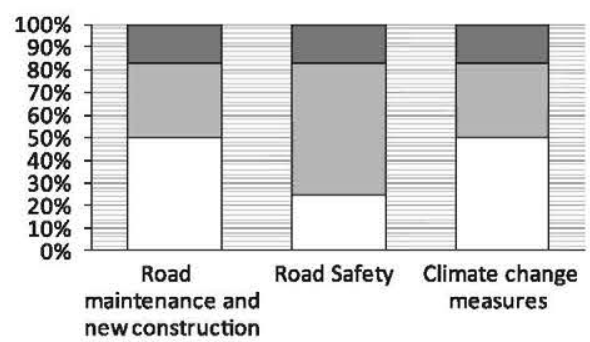

Passengers bus operators

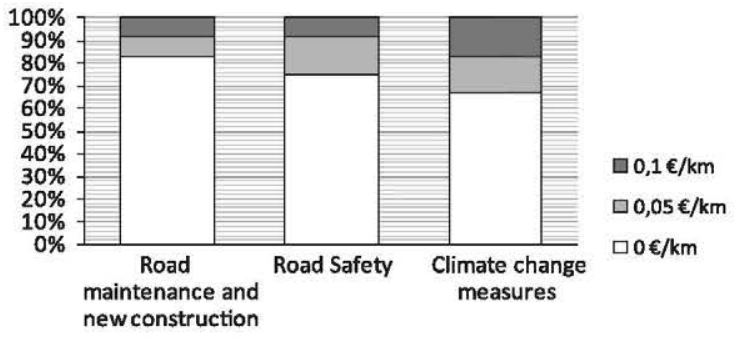

Freight operators

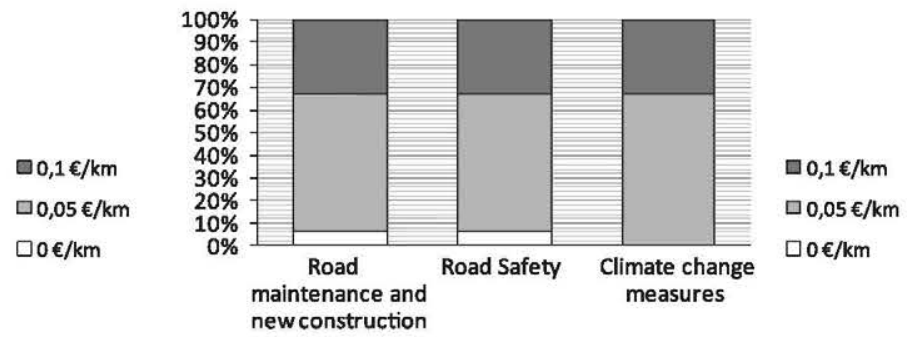

Highways concessionaires

Fig. 1. Willingness to pay by stakeholder groups with regard to toll levels and uses of revenue. 
tive for highlighting gross differences and similarities between different stakeholder groups, but has two important drawbacks: the simple descriptive analysis does not reveal what factors significantly influence the stakeholders' intentional behavior and in what way; and secondly, it does not help to understand how to predict and modify the willingness of stakeholders to accept a road pricing scheme (Link and Polak, 2003).

\section{Modeling framework}

\subsection{Discrete choice model}

It was therefore decided to develop a binary discrete-choice model ("accept" or "not accept" paying for the use of highways) and a hybrid model with latent variables. It is important to evaluate the sensitivity of the stakeholders to variations in the price. This analysis enabled us to distinguish among those respondents who had chosen the different revenue-spending combinations. In this kind of model, the main assumption is that each decision-maker seeks to maximize his personal utility and chooses the alternative with the highest utility only for himself (Ben-Akiva et al., 2009).

In this context, a binary discrete-choice model analysis is applied in order to analyze the behavior of all road stakeholders: private car users' associations, freight operators, passenger bus operators, and highway concessionaires.

The modeling framework contains a standard Multinomial Logit Model (MNL). The utility $U_{q r}$ of each stakeholder $q$ for each alternative $r$ is a function of the characteristics $S_{r q}$ of the road pricing alternative and the stakeholder' attributes (annual turnover). A set of parameters $\theta$ have to be estimated and the error term $\varepsilon_{q}$ :

$$
U_{q r}=\sum_{r} \theta_{r} \cdot S_{r q}+\varepsilon_{q}
$$

An adjustment condition is imposed through a binary variable $d_{q}$ : the utility will be positive when the individual accept the toll, or negative when he/her reject it:

$$
d_{q}=\left\{\begin{array}{l}
1 \text { if } U_{q r} \geqslant 0 \\
0 \text { in other case }
\end{array}\right.
$$

The previous tables show the discrete choice analysis with the general preference scores (Table 2) and the preference scores of each stakeholder (Table 3).

The associations of private car users are the group of stakeholders most willing to accept the implementation of a road pricing scheme (up to $70 \%$ of respondents agreed) as well as higher toll price levels (up to $43 \%$, provided that the revenue collected is used for road safety and climate change measures). This result is confirmed by the implementation of a discrete-choice model with binary choice where the car users' associations choose the highest level of toll charge. However as for the other road stakeholders, the annual turnover and the toll level are the most important explanatory variables in the discrete choice model (Tables 2 and 3).

In the case of passenger transport operators, the willingness to accept increases if the revenue generated by tolls is used for road-safety measures (72\%). However, when the data is analyzed using the binary logit model, concern for road safety diminishes as an explanation for the greater acceptance of a road charge by passenger transport operators. In fact, the target population that is readiest to pay for road safety also accepts the use of revenues to pay for other possibilities, such as new road construction. Once more, the size of a respondent bus company's annual turnover proves to be a useful explanatory variable for the respondents operating passenger buses. As with the freight operators, they are still sensitive to the toll level (Fig. 1).

The highway concessionaires agree strongly with the introduction of a road pricing scheme (only $6 \%$ chose a toll level of $€ 0 / \mathrm{vkm}$ ) (Fig. 1). As with the freight and passenger operators, annual turnover is an explanatory variable for the acceptance of highway concessionaires. However these operators are price-sensitive, and react negatively to rises in the proposed toll levels. Although the descriptive analysis shows strong sensitivity to climate change measures, the binary logit model does not regard this as an explanatory variable. In fact, the highway concessionaires never chose climate change measures alone

Table 2

General discrete choice model (binary logit) results.

\begin{tabular}{lcr}
\hline Variable & Coefficient & \multicolumn{1}{c}{$t$-Student } \\
\hline Toll level & -4.79 & $(-10.899)$ \\
More than 40 vehicles (big companies) & 1.33 & $(4.285)$ \\
Less than six vehicles (small companies) & 0.91 & $(2.071)$ \\
High annual turnover $(>€ 5,000,000)$ & 1.58 & $(5.717)$ \\
Low annual turnover $(<€ 1,000,000)$ & 2.96 & $(5.286)$ \\
Freight transport operators & -1.51 & $(-3.832)$ \\
Combined road and rail transport companies & 0.86 & $(2.106)$ \\
Highway concessionaires & 2.76 & $(7.166)$ \\
Car users' associations & 1.81 & $(5.237)$ \\
\hline
\end{tabular}


Table 3

Discrete-choice model (binary logit) results, stakeholder by stakeholder.

\begin{tabular}{|c|c|c|c|c|}
\hline Stakeholders & Variable & Coefficient & Standard error & Mean of $X$ \\
\hline Private car users' associations & $\begin{array}{l}\text { Toll level } \\
\text { Climate change sensitivity } \\
\text { Improvement of road safety } \\
\text { Low annual turnover }(<€ 1,000,000) \\
\text { Intermediate annual turnover }(€ 1,000,000-5,000,000) \\
\text { High annual turnover }(>€ 5,000,000)\end{array}$ & $\begin{array}{l}-3.76(-4.382) \\
1.17(2.139) \\
.90(1.665) \\
- \\
2.99(3.116) \\
3.65(4.268)\end{array}$ & $\begin{array}{l}.85 \\
.55 \\
.54 \\
- \\
.96 \\
.85\end{array}$ & $\begin{array}{l}1.50 \\
.50 \\
.50 \\
- \\
.17 \\
.82\end{array}$ \\
\hline Freight operators & $\begin{array}{l}\text { Toll } \\
\text { Low annual turnover }(<€ 1,000,000) \\
\text { Intermediate annual turnover }(€ 1,000,000-5,000,000) \\
\text { High annual turnover }(>€ 5,000,000)\end{array}$ & $\begin{array}{l}-1.50(-10.291) \\
3.04(4.01) \\
- \\
-\end{array}$ & $\begin{array}{l}.14 \\
.69 \\
- \\
-\end{array}$ & $\begin{array}{l}1.50 \\
.04 \\
- \\
-\end{array}$ \\
\hline Passenger operators & $\begin{array}{l}\text { Toll } \\
\text { Low annual turnover }(<€ 1,000,000) \\
\text { Intermediate annual turnover }(€ 1,000,000-5,000,000) \\
\text { High annual turnover }(>€ 5,000,000)\end{array}$ & $\begin{array}{l}-3.18(-5.088) \\
6.50(4.629) \\
- \\
4.18(4.752)\end{array}$ & $\begin{array}{l}.62 \\
1.40 \\
- \\
.88\end{array}$ & $\begin{array}{l}1.50 \\
.13 \\
- \\
.80\end{array}$ \\
\hline Highway concessionaires & $\begin{array}{l}\text { Toll } \\
\text { Low annual turnover }(<€ 1,000,000) \\
\text { Intermediate annual turnover }(€ 1,000,000-5,000,000) \\
\text { High annual turnover }(>€ 5,000,000)\end{array}$ & $\begin{array}{l}-4.22(-4.980) \\
6.34(4.020) \\
6.34(3.462) \\
8.31(4.997)\end{array}$ & $\begin{array}{l}.84 \\
1.57 \\
1.83 \\
1.66\end{array}$ & $\begin{array}{l}1.50 \\
.08 \\
.04 \\
.83\end{array}$ \\
\hline
\end{tabular}

as the object of revenue spending, but always climate change measures and another option - road construction and/or road safety - for the use of revenues derived from road tolls (Tables 2 and 3 ).

The discrete choice model analysis highlighted the wide divergence in individuals' attitudes and behavior as reflected in the SP exercise. This divergence can be explained by the psychological theory affirming that behaviors are influenced not only by attitudes but also by other factors, including subjective norms (Azjen, 1991; Eriksson et al., 2008). The introduction of latent variables in the data analysis could explain this divergence. The following sections of this article describe the introduction of a hybrid model and its advantages for the analysis of road pricing acceptability.

\subsection{Modeling acceptability with latent variables}

Choice model framework is based on the Random Utility Maximization theory (RUM) framework which comes from a microeconomic analysis of individual behavior, stated for transport by McFadden (1974, 1981). According to McFadden, transport services and infrastructures users assign weights to different attributes of road pricing scheme characterizing each of the choices and select the one that maximizes their utility (Ben-Akiva and Boccarà, 1995). In general, choice model considers the problem of acceptability analysis in an experimental way by using discrete choice modeling (Train, 2003). Transport planners are particularly interested in both the road pricing effects and the factors that determine its acceptability, in order to better foresee the impact of new pricing measures (i.e. fare policy, congestion pricing, etc.). This quantitative choice models approach emphasizes the systematic, invariant aspects of choice behavior (Ben-Akiva et al., 2002). Nevertheless, recent research demonstrates the existence of factors such as attitudes, perception and social interactions that distort - positive or negatively - the use of a transport service or infrastructure, hence partly relaxing the classic RUM assumptions including flexible disturbances error and latent variables (Cantillo et al., 2007; Yáñez et al., 2009; Tudela et al., 2011).

In the case of road pricing acceptability, the use of hybrid discrete choice models with the incorporation of psychological factors leads to a more behaviorally realistic representation of the choice process, and consequently has a better explanatory power (Cao and Mokhtarian, 2005; Heath and Gifford, 2006; Duarte et al., 2009; Karash et al., 2008). Thus a sequential maximum likelihood estimation method is used to integrate latent variables in discrete choice models. Despite the fact that this method does not guarantee totally consistent estimators, its application is clear and simple and gives good results (Yañez et al., 2010; Bolduc and Alvarez-Daziano, 2010). The latent variables are derived from the subjective attitudes and perceptions which emerged in the attitude questionnaire, while the more objective data are collected from the stated preferences experiment.

In particular, this questionnaire was designed to capture road stakeholders' perceptions of various aspects: the condition of the Spanish highway network, the institutional framework of the toll collection agency, the effects of road pricing implementation and the suitable design of a road pricing system, by posing questions such as those shown in Table 4 . Within the set of the road stakeholders' evaluable assumptions, the attitudinal questionnaire addressed the two cross-cutting issues of social responsibility and fairness, which were identified as latent variables through a preliminary exploratory factor analysis (Spearman, 1904; Bollen, 1989). However, a confirmatory factorial analysis, following the Jöreskog model (1969) identifies only fairness as a significant latent variable related to the willingness to pay for road use, while social responsibility was excluded due to its low $t$-student test, equal to -0.56 . The resulting subjective ratings of the attitudinal questions are used as indicators of the latent variable of fairness. 
Table 4

Indicators of fairness: stakeholder ratings.

\begin{tabular}{|c|c|c|c|c|c|}
\hline $\begin{array}{l}\text { Question asked: Please rate the following aspects of the road } \\
\text { tolling scheme design }\end{array}$ & $\begin{array}{l}\text { Corresponding } \\
\text { Fairness indicators }\end{array}$ & $\begin{array}{l}\text { Car users' } \\
\text { association } \\
\text { Mean } \\
\text { Median }\end{array}$ & $\begin{array}{l}\text { Freight } \\
\text { operators } \\
\text { Mean } \\
\text { Median }\end{array}$ & $\begin{array}{l}\text { Passenger } \\
\text { operators } \\
\text { Mean } \\
\text { Median } \\
\end{array}$ & $\begin{array}{l}\text { Highway } \\
\text { concessionnaires } \\
\text { Mean } \\
\text { Median }\end{array}$ \\
\hline $\begin{array}{l}\text { 1. For the same section of road, charges can vary in accordance } \\
\text { with peak and off-peak hours (with rush hour more expensive) }\end{array}$ & $\begin{array}{l}y_{1}=\text { toll adapted to } \\
\text { congestion }\end{array}$ & $\begin{array}{l}2.9 \\
3\end{array}$ & $\begin{array}{l}2.4 \\
2\end{array}$ & $\begin{array}{l}2.5 \\
3\end{array}$ & $\begin{array}{l}3.1 \\
3\end{array}$ \\
\hline $\begin{array}{l}\text { 2. The road charge should vary depending on the quality of the } \\
\text { road }\end{array}$ & $\begin{array}{l}y_{2}=\text { toll adapted to } \\
\text { road quality }\end{array}$ & $\begin{array}{l}2.9 \\
3\end{array}$ & $\begin{array}{l}2.9 \\
3\end{array}$ & $\begin{array}{l}2.9 \\
3.5\end{array}$ & 3.5 \\
\hline $\begin{array}{l}\text { 3. Road charges should apply to the entire network of roads, } \\
\text { including roads in the city }\end{array}$ & $\begin{array}{l}y_{3}=\text { tolling all road } \\
\text { network }\end{array}$ & $\begin{array}{l}1.8 \\
2\end{array}$ & $\begin{array}{l}1.6 \\
1\end{array}$ & $\begin{array}{l}2.25 \\
1.5\end{array}$ & $\begin{array}{l}1.5 \\
1\end{array}$ \\
\hline $\begin{array}{l}\text { 4. Road charges should apply only to trucks and buses weighting } \\
\text { more than } 3.5 \text { tons }\end{array}$ & $\begin{array}{l}y_{4}=\text { toll only to } \\
\text { heavy vehicles }\end{array}$ & $\begin{array}{l}2.2 \\
2\end{array}$ & $\begin{array}{l}1.1 \\
1\end{array}$ & $\begin{array}{l}1.4 \\
1\end{array}$ & $\begin{array}{l}2 \\
2\end{array}$ \\
\hline 5. Passenger cars should also have to pay for road use & $\begin{array}{l}y_{5}=\text { toll for all } \\
\text { vehicles }\end{array}$ & $\begin{array}{l}2.9 \\
3\end{array}$ & $\begin{array}{l}3.2 \\
4\end{array}$ & $\begin{array}{l}3.7 \\
4\end{array}$ & $\begin{array}{l}1.9 \\
2\end{array}$ \\
\hline $\begin{array}{l}\text { 6. Calculation of road charges should be the same throughout the } \\
\text { EU }\end{array}$ & $\begin{array}{l}y_{6}=\text { same toll } \\
\text { scheme for all EU } \\
\text { countries }\end{array}$ & $\begin{array}{l}2.5 \\
2.5\end{array}$ & $\begin{array}{l}2.6 \\
3\end{array}$ & $\begin{array}{l}3 \\
4\end{array}$ & $\begin{array}{l}2.4 \\
2.5\end{array}$ \\
\hline
\end{tabular}

\subsubsection{Definition of the hybrid model}

As shown in Table 4, the attitudinal questions and indicators of fairness 1,2,5 and 6 have high mean and median values, implying a high level of stakeholder agreement with the statements, while indicators of fairness 3 and 4 have a low value of both measures, signifying stakeholders' disagreement with the statements. In other words, stakeholders do not agree with two different aspects of equity: a spatial equity oriented to an extension of the road pricing scheme into urban areas, and fairness relating to the use of the infrastructure: pay as you use and damage the infrastructure. Consequently, we selected questions 1,2, 5 and 6 as indicators of the latent variable.

Having identified faimess as a latent variable, the next task was to verify whether its inclusion in the model increased the fitness of the previous estimated discrete choice model (DCM). The modeling scheme adopted was a hybrid model that combines a discrete choice model with a latent variable, as proposed by Ben-Akiva et al. (2002), in Fig. 2.

The latent variables in discrete choice models can be introduced in four different ways (Walker, 2001):

- Directly including the latent variable indicators in the utility function.

- Introducing latent variables, once they have been obtained from a filtered factor analysis.

- With sequential integration of the latent variables obtained from a filtered factor analysis using a multiple indicator and multiple causes model, MIMIC.

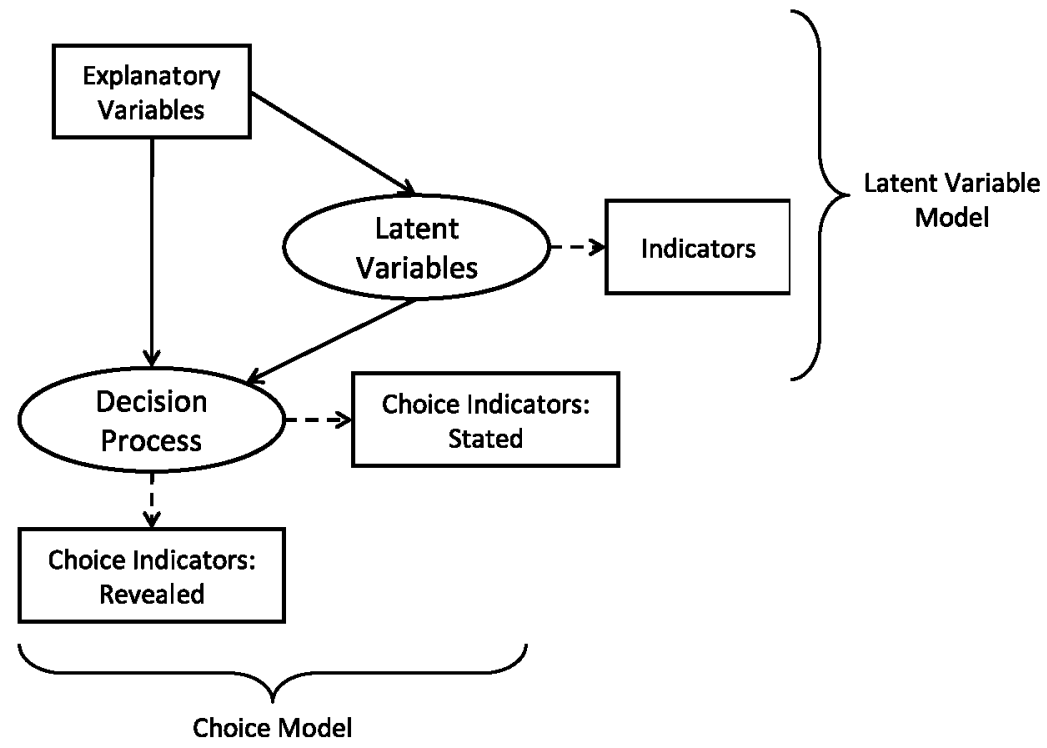

Fig. 2. Scheme of an hybrid model. Source: Ben-Akiva et al. (2002). 
- Simultaneously estimating latent attributes in the choice model structure.

The first method is discarded as it can cause serious problems of multi-colinearity, and the second can give rise to measurement errors. The estimation of the fourth method was resolved both by classical methods (likelihood function)(Ben-Akiva et al., 2009; Bolduc et al., 2008) and Bayesian methods (Bolduc et al., 2010). However, the simultaneous model system is quite complex to solve. Bolduc et al. (2005) created an experimental prototype, but the software does not cover more than three alternatives (Yañez et al., 2010). Therefore we have chosen the third method, with sequential integration. It has the drawback of not jointly using all the available information, but it is easier to apply and gives good results in terms of coefficient estimations (Ashok et al., 2002; Vredin et al., 2006; Raveau et al., 2010). In this case, we have adopted a compromise solution introducing utility as a latent variable to reduce the measurement errors of the latent variable. Following Correia et al. (2010) we have introduced the continuous variable of utility of road pricing acceptance $\left(U_{q}\right)$ as a second latent variable. The inclusion of utility as a latent variable partially counteracts the model's inconsistency.

The latent variable model is implemented by a MIMIC (Multiple Indicator Multiple Cause) model (Vredin Johansson et al., 2006). The introduction of a MIMIC model can combine explanatory variables $\left(s_{r q}\right)$ jointly with fairness indicators $\left(y_{p q}\right)$ and our pseudo-utiliy $\left(U_{q}\right)$ to estimate the latent variable of fairness $\left(\eta_{q}\right)$. This model estimates the latent variable $\eta_{q}$ (fairness) using the characteristics of the stakeholders and road pricing schemes $\left(s_{r q}\right)$ through structural equations such as (3). At the same time, the latent variable explains the perception indicators of fairness $\left(y_{p q}\right)$, which are observed by the modeler from the attitudinal questionnaire, through measurement equations such as (4). In the same way, the pseudo-utility is estimated using also characteristics of the stakeholders and road pricing schemes $\left(s_{q r}\right)$ through structural equations such as (3). We use the binary choice variable $\left(d_{p}\right)$, with 1 for acceptance of road pricing and 0 if not, as an indicator for measuring this pseudo-utility latent variable (similar as we did in Eq. (2)). We should force the indicator coefficient of the pseudo-utility ( $k$ ) to be a constant (1, in our case) in order to let fit the model (Jöreskog, 1969).

The MIMIC model estimates the latent variable of fairness by taking into account the interactions with stakeholders' characteristics and road pricing scheme attributes, both of which are factors related to road pricing acceptance:

$$
\begin{aligned}
& \eta_{q}=\sum_{r} \gamma_{r q} \cdot s_{r q}+\beta_{q} \cdot U_{q}+\xi_{\eta q} \\
& U_{q}=\sum_{r} \gamma_{r q} \cdot s_{r q}+\xi_{u q} \\
& y_{p q}=\sum_{p} \lambda_{p q} \cdot \eta_{q}+\varepsilon_{p q} \\
& d_{p}=k \cdot U_{q}+\varepsilon_{u q}, \quad d_{q}:\left\{\begin{array}{l}
1 \text { if user accept toll } \\
0 \text { in other case }
\end{array}\right.
\end{aligned}
$$

where index $q$ refers to an individual, $r$ to an explanatory variable and $p$ to an indicator of the latent variable; $\beta_{q}, \gamma_{q r}$ and $\lambda_{p q}$ are parameters to be estimated, while $\varepsilon_{\eta q}, \varepsilon_{u q} \varepsilon_{e q}$ and $\varepsilon_{p q}$ are error terms with mean zero and standard deviation to be estimated. As the $\lambda_{p q}$ (indicators of fairness) term is unknown, both Eqs. (3) and (4) must be considered jointly in the parameter estimation process. In consequence, the model framework for estimating acceptability with latent variables is represented by the scheme and system of equations of Fig. 3.

The measurement equations are given by (4) and represent the four indicators of latent variables which prove to be most significant in a confirmatory factorial analysis, from the previous six shown in Table 4, from we have already selected only four fairness indicators:

$$
\begin{aligned}
& y_{1 q}=\lambda_{1 q} \cdot \text { Fairness }_{q}+\varepsilon_{1 q} \\
& y_{2 q}=\lambda_{2 q} \cdot \text { Fairness }_{q}+\varepsilon_{2 q} \\
& y_{5 q}=\lambda_{5 q} \cdot \text { Fairness }_{q}+\varepsilon_{5 q} \\
& y_{6 q}=\lambda_{6 q} \cdot \text { Fairness }_{q}+\varepsilon_{6 q}
\end{aligned}
$$

The structural equations describing both the endogenous variables of fairness and utility are given by (3) shown above, now specified with the characteristics of stakeholders and road pricing schemes:

$$
\begin{aligned}
& \eta_{q}=\gamma_{\text {highturn }} \cdot \text { highturn }_{q}+\gamma_{\text {pas }} \cdot \text { passOper }_{q}+\gamma_{\text {conc. }} \cdot \text { conc }_{q}+\gamma_{6 f l e e t} \cdot 6 \text { fleet }_{q}+\beta_{\text {fair }} \cdot U_{q}+\xi_{q} \\
& u_{g}=\gamma_{\text {highturn }} \cdot \text { highturn }_{q}+\gamma_{\text {freight }} \cdot \text { freight }_{q}+\gamma_{40 \text { fleet }} \cdot 40 \text { fleet }_{q}+\gamma_{6 f \text { fleet }} \cdot 6 \text { fleet }_{q}+\gamma_{\text {toll }} \cdot \text { toll }_{q}+\gamma_{\text {roadconstr }} \cdot \text { roadconstr }_{q}+\gamma_{\mathrm{CO} 2} \cdot \mathrm{CO}_{q}
\end{aligned}
$$

Estimating the structural MIMIC previously defined, we obtained the results shown in Table 5. The fairness is measured by using four perception indicators regarding toll adapted to the level of congestion $\left(y_{1}\right)$, to the quality of the road $\left(y_{2}\right)$, applied to all vehicles $\left(y_{5}\right)$, and with same pricing scheme in all EU countries $\left(y_{6}\right)$. Congestion level and also road quality are very important. Stakeholders consider that pay charges for a road congested or a bar road is not fair. Thus, we measure the latent variable fairness in order to incorporate it into the binary discrete choice model (Eqs. (1) and (2)). The model outcomes are represented in Table 5. 


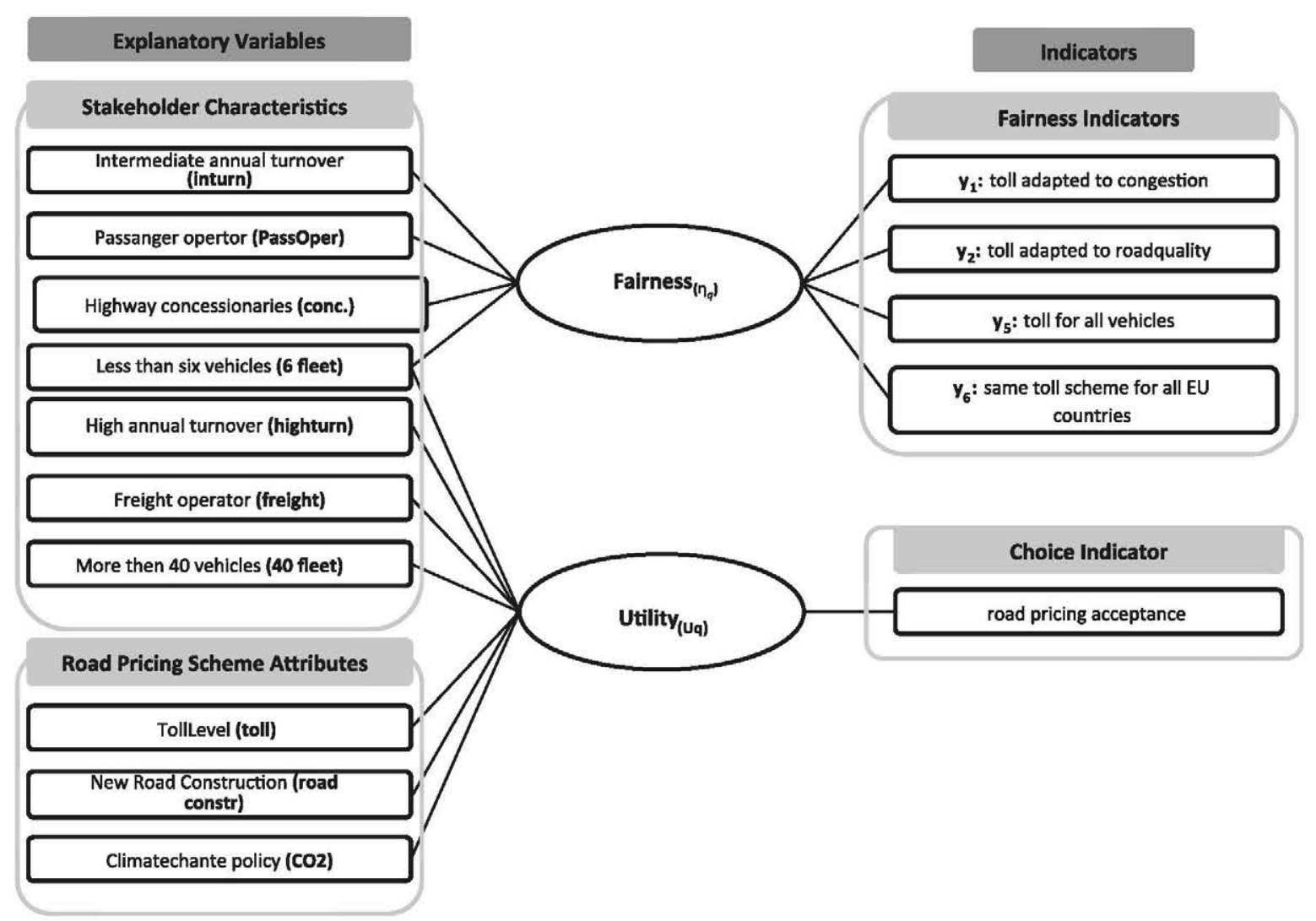

Fig. 3. MIMIC path diagram.

Table 5

Estimations of coefficients in MIMIC.

\begin{tabular}{|c|c|c|c|c|}
\hline \multicolumn{5}{|l|}{ Final results of MIMIC } \\
\hline \multirow[t]{2}{*}{ Measurement variables } & \multicolumn{4}{|c|}{ Endogenous variables } \\
\hline & Fairness $\left(\eta_{q)}\right.$ & $t$-Stud. & Utlity $\left(U_{q}\right) 1^{(*)}$ & $t$-Stud. \\
\hline \multicolumn{5}{|l|}{ Choice } \\
\hline \multicolumn{5}{|l|}{$A-Y$} \\
\hline$Y_{1}$ : toll adapted to congestion & 0.93 & $\left(*^{*}\right)$ & - & \\
\hline$Y_{2}:$ toll adapted to road quality & 0.8 & $(-25.87)$ & - & \\
\hline$Y_{5}:$ toll for all vehicles & 0.71 & $(23.13)$ & - & \\
\hline$Y_{6}$ : same toll scheme for all EU countries & 0.65 & $(22.05)$ & - & \\
\hline \multicolumn{5}{|l|}{ B } \\
\hline Fairness & - & & - & \\
\hline Utility & 0.03 & $(1.62)$ & - & \\
\hline \multicolumn{5}{|l|}{$\gamma$} \\
\hline Intermediate annual turnover $(c 1,000,000-5,000,000)$ & -0.56 & $(-8.54)$ & - & \\
\hline High annual turnover $(>C 5,000,000)$ & - & & 0.08 & $(0.81)$ \\
\hline Freight operators & - & & -0.39 & $(-7.11)$ \\
\hline Passenger operators & 0.19 & $(5.29)$ & - & \\
\hline Highway concessionaires & -0.06 & $(-2.17)$ & - & \\
\hline Less than six vehicles & 0.22 & $(2.68)$ & -0.42 & $(-5.51)$ \\
\hline More than 40 vehicles & - & & -0.33 & $(-4.29)$ \\
\hline Toll level & - & & -0.34 & $(-1.92)$ \\
\hline New road construction & - & & -0.58 & $(-1.38)$ \\
\hline Climate change policy measures $\left(\mathrm{CO}_{2}\right)$ & - & & -0.54 & $(-1.35)$ \\
\hline
\end{tabular}

*fixed parameter 
With the incorporation of the latent variable $\eta_{q}$ a new formulation of the utility is obtained, here $\theta_{r}$ and $\theta_{\eta}$ are the parameters to be estimated associated with the attributes and the latent variable. Its formulation is showed in Eq. (7)

$$
U_{q r}=\sum_{r} \theta_{r} \cdot S_{r q}+\theta_{\eta} \cdot \eta_{q}+\varepsilon_{q}
$$

The advantage of estimating latent variables is that the measuring errors are minimized.

The results show the importance of the perception of fairness in the acceptance of the implementation of a road pricing scheme. This result confirms one of the main hypotheses of the literature on road pricing acceptability, namely that the degree of acceptability of a road pricing scheme is strongly linked to the perception of fairness by users (Schade and Schlag, 2003; Verhoef et al., 1997; Ubbels and Verhoef, 2006; Eriksson et al., 2008).

\subsubsection{Hybrid model results}

The comparison between the results produced by a discrete choice model and a hybrid model is useful in two ways: to check the fit and to improve the estimation by the inclusion of latent variables. The integration of subjective attitudes and perceptions (latent variable) derived mainly from the attitude questionnaire with the more objective data collected by the stated preference experiment improves the analysis of road pricing acceptability. The results show that the implementation of a road pricing system is not readily accepted. The importance of a latent variable such as fairness indicates that road pricing will be accepted if the toll is perceived to be fair by the road stakeholders.

The main result is that the introduction of latent variables offers a better understanding of road pricing acceptability by stakeholders. The latent variable fairness results the most explanatory power after level of toll and the size of the company and "highway concessionaires" (i.e. bold values). A comparison of the estimations using both different models shows that, in general, the hybrid models improve the analysis of road pricing acceptability (Table 6).

The hybrid model increases the explicability of the results and the predictability of the model by $16 \%$, as shown in the normalized index in Table 6 . The normalized index allows various models of the same phenomena to be compared, but using different variables (Ortúzar and Willumsen, 2001).

Table 7 compares the parameters of the variables in both models. They indicate that car users' associations are the stakeholder group most willing to accept the implementation of a road pricing scheme, provided that the revenue collected is used for climate change measures. On the other hand, freight transport operators are generally opposed to the implementation of a road pricing scheme. However, freight companies operating combined road and rail services show a positive willingness to pay for road use (0.86 in the DCM and 0.93 in the MIMIC, Table 7) as they are more sensitive to congestion problems, and the revenues from tolls could be dedicated to rail improvement. The latent variable of fairness represents the forth more important variable explaining the stakeholders willingness to pay (2.23) with a high significance (4.283). In other words, when stakeholder perceives the toll as fair,

Table 6

Comparing the discrete choice model and hybrid model results.

\begin{tabular}{lll}
\hline & DCM & Hybrid model \\
& Binary logit & MIMIC + binary logit \\
\hline McFadden pseudo $r$ square & 0.350 & 0.372 \\
Predicting results & $79.2 \%$ & $81.0 \%$ \\
Normalized index & 0.48 & 0.57 \\
\hline
\end{tabular}

Table 7

Comparing the estimated parameters of both models.

\begin{tabular}{|c|c|c|c|c|}
\hline & \multicolumn{2}{|c|}{$\begin{array}{l}\text { DCM } \\
\text { Binary logit }\end{array}$} & \multicolumn{2}{|c|}{$\begin{array}{l}\text { Hybrid model } \\
\text { MIMIC + Binary logit }\end{array}$} \\
\hline & Coef. & $t$-Student & Coef. & $t$-Student \\
\hline Toll level & -4.79 & $(-10.899)$ & -5.5 & $(-11.161)$ \\
\hline More than 40 vehicles & 1.33 & $(4.285)$ & 0.72 & $(2.219)$ \\
\hline Less than six vehicles & 0.91 & $(2.071)$ & 0.69 & $(1.586)$ \\
\hline High annual turnover $(>€ 5,000,000)$ & 1.58 & $(5.717)$ & 1.13 & $(3.848)$ \\
\hline Low annual turnover $(<€ 1,000,000)$ & 2.96 & $(5.286)$ & 2.71 & $(4.812)$ \\
\hline Freight operators & -1.51 & $(-3.832)$ & -1.91 & $(-4.655)$ \\
\hline Combined road and rail transport companies & 0.86 & $(2.106)$ & 0.93 & $(2.252)$ \\
\hline Highway concessionaires & 2.76 & $(7.166)$ & 2.24 & $(5.575)$ \\
\hline Car users' associations & 1.81 & $(5.237)$ & 1.04 & $(2.736)$ \\
\hline Climate change policy (significant only for car user associations) & 0.44 & $(1.774)$ & 0.53 & $(2.100)$ \\
\hline Fairness & - & - & 2.23 & $(4.283)$ \\
\hline
\end{tabular}


he easily accepts to pay for it. Therefore, the inclusion of latent variables in discrete choice modelling framework and the estimation of hybrid models reveals a great potential for improving the analysis of the acceptability (see Fig. 3).

\section{Conclusion: policy implications and perception of fairness}

The results of the survey show that stakeholder groups in Spain consider environmental and safety problems to be relevant ( $46 \%$ and $51 \%$ respectively) to road use and road revenues, but they are not eager to pay to alleviate these problems. In other words, social responsibility is not an important factor for Spanish stakeholders in the acceptance of a road pricing scheme. The only group among all the stakeholders which would agree to pay for $\mathrm{CO}_{2}$ emissions reduction is car users' associations. The freight companies serving combined road and rail transport services are more willing to pay for the use of roads. Different groups of stakeholders give different answers, although the logit models for each stakeholder based on the SP survey indicate that the level of charge is relevant to the acceptability of pricing schemes in all cases. Private car users' associations agree with the payment of tolls in order to reduce GHG emissions. Bus operators are willing to pay only in order to reduce accidents, while freight operators are unwilling to pay whatever the reason, except for freight companies of combined road and rail transport. Highway concessionaires are the only group that clearly supports the charging system, but they prefer a moderate to high level of fees. The income level of the company also influences the views on acceptability, but not homogeneously.

When the analysis is extended to include psychological variables by means of a MIMIC model, it can be seen that part of the charge level - the forth most important explanatory factor - is the latent variable of fairness. This result highlights the fact that the incorporation of psychological factors in a Random Utility Model (RUM) leads to a more behaviorally realistic representation of the choice process. In fact, an hybrid model reveals the weight of the latent psychosocial variables in usersstakeholders decisions and identifies their complementary explanatory power with regard to observable variables like toll level, income level and type of stakeholder (Golob, 2001; Pendleton and Shonkwiler, 2001; Fujii and Gärling, 2003; Vredin Johansson et al., 2006).

This research shows that pricing policy for European road networks faces considerable problems as to its acceptability by the relevant stakeholder groups. The hybrid model results show that the acceptability of tolls increases when it is perceived as fair. The measurement of fairness has been possible by introducing a latent variable in the discrete choice model crossing Stated Preferences data and attitudinal survey results. Therefore, policy-makers should act on fairness perception of tolls as a way to improve acceptability. According to the results, the stakeholders have higher acceptance when the toll is apply to all type vehicles and to all the countries. Policy makers should definitely promote the perception of the fairness in order to increase the road pricing acceptability by stakeholders.

\section{Acknowledgements}

The authors would like to thank the Infrastructure and Transport Ministry Study Institute (CEDEX) for its support in formulating the Spanish road pricing model (META). We thank the TRANSyT Researcher Julio Comendador for helping in the collection and organization of the survey data.

\section{References}

Ashok, K., Dillon, W.R., Yuan, S., 2002. Extending discrete choice models to incorporate attitudinal and other latent variables. Journal of Marketing Research $39(1), 31-46$.

Azjen, I., 1991. The theory of planned behavior. Organizational Behavior and Human Decision Process 50, 179-211.

Bamberg, S., Rölle, D., 2003. Determinants of people's acceptability of pricing measures - Replication and extension of a causal model. In: Schade, J., Schlag, B. (Eds.), Acceptability of transport pricing strategies. Elsevier Science, Oxford, pp. 235-248.

Ben-Akiva, M., Boccarà, B., 1995. Discrete choice models with latent choice sets. International Journal of Research in Marketing 12, 9-24.

Ben-Akiva, M., Mcfadden, D., Train, K., Walker, J., Bhat, C., Bierlaire, M., Bolduc, D., Boersch-Supan, A., Brownstone, D., Bunch, D.S., Daly, A., De Palma, A., Gopinath, D., Karlstrom, A., Munizaga, M.A., 2002. Hybrid choice models: progress and challenges. Marketing Letters 13, 163-175.

Ben-Akiva, M., Bierlaire, M., Bolduc, D., Walker, J., 2009. Discrete Choice Analysis. MIT Press, MA, pp. 338-378.

Ben-Akiva, M., de Palma, A., McFadden, D., Abou-Zeid, M., Chiappori, P.A., de Lapparent, M., Durlauf, S., Fosgerau, M., Fukuda, D., Hess, S., Manski, C., Pakes, A., Picard, N., Walker, J., 2012. Process and context in choice models. Marketing Letters 23 (2), 439-456.

Bolduc, D., Alvarez-Daziano, R., 2010. On estimation of hybrid choice models. In: Hess, S., Daly, A. (Eds.), Choice Modelling: The State-of-the-Art and the State-of-Practice. Proceedings from the Inaugural International Choice Modeling Conference, Emerald, England.

Bolduc, D., Ben-Akiva, M., Walder, J., Michaud, A., 2005. Hybrid choice models with logit kernel: applicability to large scale models. In: Lee-Gossein, Doherty (Ed.), Integrated Land-use and Transportation Models: Behavioral Foundations. Elsevier.

Bolduc, D., Boucher, N., Âlvarez-Daziano, R., 2008. Hybrid choice modeling of new technologies for car choice in Canada. Transportation Research Record $2082,63-71$.

Bollen, K.A., 1989. Structural Equations with Latent Variables. John Willey and Sons, New York.

Cantillo, V., Ortúzar, J. de D., Williams, H.C.W.L., 2007. Modeling discrete choices in the presence of inertia and serial correlation. Transportation Science 41, 195-205.

Cao, X., Mokhtarian, P.L., 2005. How do individuals adapt their personal travel? Objective and subjective influences on the consideration of travel-related strategies for San Francisco Bay Area commuters. Transport Policy 12, 291-302.

Commision of the European Communities (CEC), 2001. White Paper European Transport Policy 2010: Time to Decide. Brussels.

Commision of the European Communities (CEC), 2006. Directive 2006/38. Brussels.

Commision of the European Communities (CEC), 2008. Proposal 2008/0147 for a Directive of the Heavy Goods Vehicles for the Use of Certain Infrastructures. Brussels. 
Commision of the European Communities (CEC), 2011. Directive 2011/76. Brussels.

Condeço-Melhorado, A., Gutiêtrez, J., García-Palomares, J.C., 2011. Spatial impacts of road pricing: accessibility, regional spillovers and territorial cohesion. Transportation Research Part A: Policy and Practice 45 (3), 185-203.

Correia, G., Abreu e Silva, J., Viegas, J., 2010. Using latent attitudinal variables for measuring carpooling propensity. In: Proceeding of 12th World Conference on Transport Research. Lisbon.

De Groot, J., Steg, L., 2006. The role of value orientations in evaluating quality of life consequences of a transport pricing policy. Transportation Research Part D $11(2), 160-165$.

Di Ciommo, F., Monzôn, A., Comendador, J., 2010. Road transport social costs in Spain: a new rationale for pricing policy. In: Selected Proceeding of 12th World Conference of Transport Research, Lisbon. ISBN: \#978-989-96986-1-1.

Duarte, A., Garcia, C., Limão, S., Polydoropoulou, A., 2009. Experienced and expected happiness in transport mode decision making process. In: Proceeding 88th Annual Meeting of the Transportation Research Board.

Eriksson, L., Garvill, J., Nordlund, A.M., 2008. Acceptability of single and combined transport policy measures: the importance of environmental and policy specific beliefs. Transportation Research Part A 42, 117-1128.

Frey, B.S., 2003. Why are efficient transport policy instruments so seldom used. In: Schade, J., Sclag, B. (Eds.), Acceptability of Transport Pricing Strategies. Elsevier, Oxford, pp. 63-76.

Fridstrøm, L., Minken, H., Moilanen, P., Shepherd, S.P., Vold, A., 2000. Economic and Equity Effects of Marginal Cost Pricing in Transportation. VATT Research Report 71, Helsinki, Finland.

Fujii, S., Gärling, T., 2003. Application of attitude theory for improved predictive accuracy of stated preference methods in travel demand analysis. Transportation Research Part A: Policy and Practice 37, 389-402.

Gaunt, M., Rye, T., Allen, S., 2007. Public acceptability of road user charging: the case of Edinburgh and the 2005 Referendum. Transport Reviews 27 (1), $85-$ 102.

Golob, T.F., 2001. Joint models of attitudes and behavior in evaluation of the San Diego I-15 congestion pricing project. Transportation Research Part A: Policy and Practice 35, 495-514.

Heath, Y., Gifford, R., 2006. Extending the theory of planned behavior: predicting the use of public transportation. Journal of Applied Social Psychology 32 , 2154-2189.

Ison, S.G., Rye, T., 2005. Implementing road user charging: the lessons learnt from Hong Kong, Cambridge and Central London. Transport Reviews 25 (4), $451-465$.

Jaensirisak, S., Wardman, M., May, A.D., 2005. Explaining variations in public acceptability of road pricing schemes. Journal of Transport Economics and Policy 39 (2), 127-153.

Jakobsson, C., Fujii, S., Gärling, T., 2000. Determinants of private car users' acceptance of road pricing. Transport Policy 7, $153-158$.

Jones, P., 1998. Urban Road Pricing: Public Acceptability and Barriers to Implementation. In: Button, K.J., Verhoef, E.T. (Eds.), Road Pricing, Traffic Congestion and Environment. Edward Elgar, USA.

Jones, P., 2003. Acceptability of transport pricing strategies: Meeting the challenge. In: Schade, J., Schlag, B. (Eds.), Acceptability of transport pricing strategies. Elsevier Science, Oxford, pp. 27-62.

Jöreskog, K.G., 1969. A general approach to confirmatory maximum likelihood factor analysis. Psychometrika 34, 183-202.

Karash, K.H., Coogan, M.A., Adler, T., Cluett, C., Shaheen, S.A., Azjen, I., Simon, M., 2008. Understanding how Individuals make Travel and Location Decisions: Implications for Public Transportation. Transportation Research Board, Washington, DC

Kottenhoff, K., Brundell-Freij, K., 2009. The role of public transport for feasibility and acceptability of congestion charging - the case of Stockholm. Transportation Research Part A 43, 297-305.

Link, H., 2007. Acceptability of the German charging scheme for heavy goods vehicles: empirical evidence from freight company survey. Transport Reviews $28(2), 141-158$

Link, H., Polak, J., 2003. Acceptability of transport pricing measures among public and professionals in Europe. Transportation Research Record 1839 , 34-44.

Litman, T., 1996. Using road pricing revenue: economic efficiency and equity considerations. Transportation Research Record 1558, 24-28.

Mayeres, I., Proost, S., 2002. Reforming Transport Pricing: An Economist's Perspective on Equity, Efficiency and Acceptability. Energy, Transport and Environment. Working Papers Series Katholieke Universiteit Leuven, Centrum voor Economische Studiën, Energy, Transport and Environment.

McFadden, D., 1974. The measurement of urban travel demand. Journal Public Economics 3, 303-328.

McFadden, D., 1981. Econometric models of probabilistic choice. In: Manski y, C.F., McFadden, D. (Eds.), Structural Analysis of Discrete Data and Econometric Applications. MIT Press, Cambridge, MA.

MIFO, 2007. Anuario Estadístico 2006. Ministerio de Fomento.

Ortúzar, J. de D., Willumsen, L.G., 2001. Modeling Transport, third ed. John Wiley and Sons, Chichester.

PATS Consortium, 2001. Pricing Acceptability in the Transport Sector. Recommendations on Transport Pricing Strategies. Final Report of the PATS Project, European Commission, Brussels, Belgium.

Pendleton, L.H., Shonkwiler, J.S., 2001. Valuing bundled attributes: a latent characteristics approach. Land Economics 77, $118-129$.

Pridmore, A., Miola, A., 2011. Public Acceptability of Sustainable Transport Measures, Discussion Paper n. 2011-20, OECD/ITF

Raveau, S., Alvarez-Daziano, R., Yáñez, M.F., Bolduc, D., Ortúzar, J. de D., 2010. Sequential and simultaneous estimation of hybrid discrete choice models: some new findings. Transportation Research Record.

Rienstra, S.A., Rietveld, P., Verhoef, E.T., 1999. The social support for policy measures in passenger transport. A statistical analysis for the Netherlands. Transportation Research D 4, 181-200.

Schade, J., 2003. European Research Results on Transport Pricing Acceptability. In: Schade, J., Schlag, B. (Eds.), Strategies. Acceptability of Transport Pricing, Elsevier, Oxford, pp. 109-123.

Schade, J., Baum, M., 2007. Reactance or acceptance? Reactions towards the introduction of road pricing. Transportation Research Part A $41,42-48$.

Schade, J., Schlag, B., 2003. Acceptability of urban transport policy strategies. Transportation Research Part F 6, 45-61.

Schlag, B., Teubel, U., 1997. Public acceptability of transport pricing. IATSS Research 21, 134-142.

Schuitema, G., Steg, L., Vlek, C., 2007. Are pricing policies effective to change car use? IATSS Research 31 (1), 21-31.

Spearman, C., 1904. General intelligence, objectively determined and measured. American Journal of Psychologist 15, 201-293.

Swicher, Ungemah, 2006. So do you want to make a HOT Lane? The project manager's guide for an HoV-to-HoT conversion. In: Proceeding of the Transportation Research Board 85th Congress, Washington, DC.

Teubel, U., 2000. The welfare effects and distributional impacts of road user charges on commuters - an empirical analysis of Dresden. International Journal of Transport Economics 27, 231-255.

Train, K.E., 2003. Discrete Choice Methods with Simulation. Cambridge University Press, Cambridge.

Tudela, A., Habib, K.M.N., Carrasco, J.A., Osman, A.O., 2011. Incorporating the Explicit Role of Psychological Factors on Mode Choice. A Hybrid Mode Choice Model by using Data from an Innovative Psychometric Survey. Paper Presented at the 2nd International Choice Modelling Conference, Leeds.

Ubbels, B., Verhoef, E., 2006. Behavioural responses to road pricing. Empirical results from a survey of Dutch car owners. Transportation Research Record 1960, 159-166.

Ungemah, D., Collier, T., 2007. I'll tell you what I think. Transportation Research Record 1996, 66-73. 
Vassallo, J.M., Solís, C., Pérez-Martínez, P.J., Pérez de Villar, P., 2008. Balance económico: fiscal, social y medioambiental del transporte de mercancías en España, Report Spanish Truking Association (Fundaciôn Corell), Madrid.

Verhoef, E.T., Nijkamp, N., Rietveld, P., 1997. The social feasibility of road pricing: a case study for the Randstad Area. Journal of Transport Economics and Policy 31, 255-276.

Vredin Johansson, M., Heldt, T., Johansson, P., 2006. The effects of attitudes and personality traits on mode choice. Transportation Research Part A: Policy and Practice 40, 507-525.

Vrtic, M., Schuessler, N., Erath, A., Axhausen, K.W., 2007. Design Elements of Road Pricing Schemes and their Acceptability. Transportation Research Board 86th Congress, Washington, DC

Walker, Joan, 2001. Extended discrete choice models: integrated framework, flexible error structures and latent variables. PhD Thesis, Massachusetts Institute of Technology, USA.

Winslott-Hiselius, L., Brundell-Freij, K., Vangland, A., Byström, C., 2009. The development of public attitudes towards the Stockholm congestion trial. Transportation Research Part A 43, 269-282.

Yăñez, M.F., Cherchi, E., Ortúzar, J. de D., Heydecker, B., 2009. Intertia and shock effects on mode choice panel data: Implications of the Transantiago Implementation. In: 12 th International Conference on Travel Behaviour Research, Jaipur, India.

Yañez, M.F., Raveau, S., Ortúzar, J., de, D., 2010. Inclusion of latent variables in mixed logit models: modelling and forecasting. Transportation Research Part A $44,744-753$ 